\title{
MORPHOLOGY, ECOLOGY AND DISTRIBUTION OF ISOETES L. IN TASMANIA
}

\author{
by Michael Garrett and Gintaras Kantvilas
}

(with one table and seven text-figures)

\begin{abstract}
GARRETT, M. \& KANTVILAS, G., 1992 (31:x): Morphology, ecology and distribution of Isoetes L. in Tasmania. Pap. Proc. R. Soc. Tasm. 126: 115-122. https://doi.org/10.26749/rstpp.126.115 PO Box 49, Bicheno, Tasmania, Australia 7215 (MG); and Tasmanian Herbarium, GPO Box 252C, Hobart, Tasmania, Australia 7001 (GK).
\end{abstract}

Five species of Isoetes are known in Tasmania. I. elatior, I. humiliorand I. gunnii are endemic, whilst I. drummondii and I. muelleri are also widespread in mainland Australia. Distinguishing morphological characteristics, distribution and ecology of the species are discussed. I. muelleri is much more common and widespread than originally thought, and many new records have been made for I. drummondii, I. elatior and $I$. humilior, enabling a better understanding of the ecology and conservation status of the genus in Tasmania.

Key Words: Isoetes, Pteridophytes, Tasmania, fern allies, endemic.

\section{INTRODUCTION}

Isoetes, a genus of the fern allies, consists of some 130 species (Jermy 1990) and is widely distributed in temperate and tropical regions of the world (Hall 1971, Mickel 1979). It is the sole genus of the family Isoetaceae within the class Lycopsida, and is comprised of the subgenera Isoetes, Stylites and Euphyllum (Hickey 1990). Its closest living relatives include Lycopodium, Phylloglossum and Selaginella .

In the Australasian region, Isoetes exhibits a large degree of localised endemism. All five species known from Papua New Guinea are endemic (Leach \& Osborne 1985), as are the two New Zealand species (Brownsey \& SmithDodsworth 1989). Fifteen species are known from Australia including Tasmania (R.J. Chinnock in litt.), of which six are confined to Western Australia (Johnson 1984), one each to the Northern Territory, South Australia and Victoria, and three to Tasmania. The genus thus shows a remarkable level of endemism in comparison to other pteridophytes in Tasmania, of which only five out of a total of approximately 100 species are endemic.

In Tasmania, Isoetes is represented by five species but, with the exception of the abundant and conspicuous I. gunnii, the genus has been poorly collected and data on its distribution are scant. A recent and ongoing survey of pteridophyte distribution in Tasmania has revealed that species of Isoetes in Tasmania are far more abundant than previously supposed. The present paper presents new information on their habitat, ecology, distribution and morphological characteristics.

\section{METHODS}

Data are derived from the first author's field observations, and from the study of living material and dried herbarium specimens. Representative specimens are lodged in the Tasmanian Herbarium (HO).

Fieldwork was undertaken from December to April between 1989 and 1991. These months are regarded as the most conducive to collecting Isoetes in Tasmania: it is the time of lowest water levels and still, sunny days which make possible the location and in situ study of the various species. Distribution maps for the species are presented using a format consistent with Brown et al. (1983) for the Tasmanian endemic flora.

\section{GENERAL CHARACTERISTICS OF THE GENUS}

\section{Morphology}

Isoetes has a tuft of grass-like leaves arising from a greatly shortened axis, usually referred to as a corm. The corm may be two- or three-lobed in Australian species, although lobing can vary within the species (Marsden 1976) and may be difficult to determine. Consequently, this character is best avoided in differentiating the species. The corm is always buried deep in mud or amongst rocks, and the entire plant must be removed to determine its character. Numerous, thick, light to dark-brown roots arise from the furrows between the lobes, and are usually dichotomously branched towards their tips. Plants can occur as discrete individuals, often in colonies, or as a dense, continuous sward.

The sporophylls (referred to hereafter as leaves) are the visible part of the growing plant and, together with the corm, may be buried for over half their length in the substrate. They are basically cylindrical, but flattened on their adaxial side from the base for part of their length. Depending upon the species, leaves may vary from thin and flaccid to thick and rigid. Their colour is generally light to dark green, with the buried section white or brown. Numerous pale or white transverse septa that partition internal air chambers are clearly visible on the leaves of most species. New leaves arise from the centre of the plant. All are abruptly widened at their bases, where they sheath the corm apex and produce a swollen base to the plant. The presence of basal sporangia further accentuates the bulbous appearance of the plant.

Single large sporangia occur on the adaxial side of the broadened leaf bases, virtually on every leaf of a mature plant. Their size and shape varies within a single species, ranging from orbicular to elliptical and from 2-10 mm 
wide. Megasporangia and microsporangia are superficially identical. They may be naked, dark brown to black and very conspicuous when mature, or completely (or rarely partially) covered by a velum. In the latter case, the dark spore mass is usually just visible through the velum. In most species, the spore mass is also usually just visible through the abaxial side of the leaf base. Megaspores are white or grey, very large (up to $750 \mu \mathrm{m}$ in I. muelleri Marsden 1976) and individually easily visible to the naked eye. Megaspore ornamentation varies between species and is best viewed when megaspores are dry. Microspores are dark brown in mass when wet and are only visible to the naked eye in mass. Morphological characters of the Tasmanian species are summarised in table 1.

Interspecific hybridisation amongst overseas populations of Isoetes is well documented (Hickey et al. 1989, Jermy 1990) but to date, no hybrids have been recorded in Tasmanian populations.

\section{Habitat}

In Tasmania, Isoetes is an aquatic or, less commonly, semiaquatic plant of fresh water. It grows predominantly in mud or silt in the still or slow-moving waters of rivers and lakes, especially in expanses of flat land such as the Central Plateau and Midlands, or broad river systems such as the Derwent and Fingal Valleys. Occasionally, it may occur also in faster flowing sections of rivers with relatively silt-free beds. The habitat of the Tasmanian species is summarised in table 1.

\section{KEY TO ISOETES SPECIES IN TASMANIA}

1. Sporangium wholly (or rarely partially) covered by a velum

Sporangium lacking a velum. 3

2. Leaves rigid and erect. Megaspores and microspores present. Plant of alpine and sub-alpine areas only 4. 1. humilior

Leaves flexible. Megaspores only present.

Plant of lowland to alpine altitudes .........5. I. muelleri

3. Leaves rigid and erect, $2-5 \mathrm{~mm}$ thick in midsection. Plant of alpine and sub-alpine areas only

Leaves soft and flexible, $1-2 \mathrm{~mm}$ thick in mid-section 3. I. gunnii

4. Leaves to $0.12 \mathrm{~m}$ long. Plant of still, shallow water or drying mud, ranging from lowland to alpine altitudes ............................ 1. I. drummondii Leaves $0.25-0.7 \mathrm{~m}$ long. Plant of permanent, running water in lowland rivers .................2. I. elatior

\section{Isoetes drummondii A. Braun}

\section{Monatsber. K. Akad. Wiss. Berlin 573 (1863)}

\section{Diagnostic Characters (Fig. 1E)}

Plants single or in colonies. Corm 2- or 3-lobed. Leaves usually spreading, sometimes erect if in deep water, devoid of algae or silt build-up, bright green (except for a pale or white buried basal section), flexible and slender, gradually tapering to a point, to $0.12 \mathrm{~m}$ long (usually c. $75 \mathrm{~mm}$ ) and $1.5 \mathrm{~mm}$ wide in middle section, very noticeably flattened on the adaxial side for most of their length. Sporangia naked, both megasporangia and microsporangia present. Megaspores finely tuberculate.

\section{Notes}

I. drummondii is best recognised by its spreading habit, clean, green, markedly flattened leaves, and its habitat (see below). The freshness of its leaves suggests that old leaves may be shed each season. In general, the species tends to have very exaggerated, swollen leaf bases, particularly when growing in drier sites, suggesting that this may be a mechanism for protection or food storage through periods of drought.

\section{Distribution}

This species appears to be uncommon in Tasmania. It is known from scattered localities on the Central Plateau between 900 and $1020 \mathrm{~m}$ above sea level, such as. Wihateja Lagoon, Ripple Creek, Camerons Lagoon and Shannon Lagoon. It is locally frequent on the shores of Lake Leake $(600 \mathrm{~m})$ on the central east coast, and nearby at Ladies Mile Marsh. There is a small population on the lower Apsley River, $4 \mathrm{~km}$ southwest of Bicheno. It is also rare in a small lagoon south of Cleveland in the Midlands, and was collected near Georgetown by W.M. Curtis (fig. 3). The species is also known from all Australian states except the Northern Territory (R.J. Chinnock in litt.).

\section{Habitat and Ecology}

1. drummondii grows in mud in shallow, still waters, or at their seasonally dry margins, and is as equally abundant in man-made water channels and waterholes as in natural sites. However, its requirement for a permanent covering of water is not as critical as for most other Tasmanian species of Isoetes. For example, in midsummer in Hortons Creek at Stonehouse Bridge, Ladies Mile Marsh, some plants occur in mud to a depth of $0.15 \mathrm{~m}$ below the water surface, but most grow in drying sections of man-made ditches and the creek, buried deep in moist, muddy clay. The leaves of plants farthest from water were starting to wilt and decay. Elsewhere in the area, I. drummondii hardly behaves as an aquatic at all, with robust plants growing amongst a dense sward of grasses and herbs in moist soil, the majority being grazed back to the rootstock by animals.

In most other sites in Tasmania, $I$. drummondii occurs with little, if any, competition from other plants." Although generally preferring shallower water, it often grows with $I$. muelleri, e.g. along the rocky shores of Lake Leake, a superficially unusual habit, where the species colonises the silt and mud amongst the rocks.

\section{Selected specimens examined}

TASMANIA: Roadside soak between Epping Forest and Conara, 200m, W.M. Curtis 22.xii.1955 (HO 126571). Road to aerodrome [Georgetown], W.M. Curtis 19.xii.1955 (HO 25248). Stonehouse Bridge, Lake Leake Road, 610m, M. Garrett 13.xii. 1990 (HO 126392). Cider Marsh, $860 \mathrm{~m}$, W.M. Curtis 11.i.1970 (HO 114702). 


\section{Isoetes elatior F. Muell. ex A. Braun Linnaea: 25: 722 (1852)}

Diagnostic Characters (figs 1A, 2A)

Plant single or in colonies. Corm 3-lobed. Leaves erect (in still water) or often swept sideways (in running water), clean or with dense build-up of algae or silt, light green except for a pale or white, buried basal section, very thin and flaccid, to $0.70 \mathrm{~m}$ long (usually c. $0.25-0.30 \mathrm{~m}$ ) and $2 \mathrm{~mm}$ wide in middle section, distinctly flattened on the adaxial side for at least half their length. Sporangia naked, both megasporangia and microsporangia present. Megaspores finely tuberculate.

Notes

I. elatior is one of the largest species of the genus in Australia, rivalled in size only by the northern Australian species I. coromandelina. Leaf width of both large and small plants tends to be much the same and consequently the latter can be practically identical with I. muelleri, especially when both species co-occur and are covered with algae. However, I. elatior is easily recognised by the absence of a velum, with large plants also possessing very noticeable membranous marginal flaps which extend up the leaf to $0.10 \mathrm{~m}$ beyond the broadened leaf base.

I. elation can also be confused with I. drummondii, but the two species grow in entirely different habitats and are unlikely to be found together. They occur $3 \mathrm{~km}$ apart on the Apsley River, but under different conditions. Nevertheless, an exceptionally tall specimen of $I$. drummondii from South Australia was mis-identified as I. elatiorin the past (Duncan \& Isaac 1986).

Distribution

I. elatior is endemic to Tasmania and appears to be the rarest of the species. It is also the only one restricted to the lowlands. The species was originally described from an unknown location on the South Esk River, and an adrift plant has since been collected from the Lake River at Longford by D.I. Morris. During the present survey, it was recorded from the South Esk River near Avoca and Fingal, at a number of sites on the St Pauls River, from the Break O'Day River, and in the lower reaches of the Apsley River (fig. 4). These collections

Table 1

Morphology and habitat of Isoetes in Tasmania

\begin{tabular}{|c|c|c|c|c|c|}
\hline & I. muelleri & 1. humilior & 1. elatior & I. drummondii & $I \cdot g u n n i i$ \\
\hline Velum & present & present & absent & absent & absent \\
\hline Spores & megaspores & $\begin{array}{l}\text { megaspores } \\
\& \text { microspores }\end{array}$ & $\begin{array}{l}\text { megaspores } \\
\& \text { microspores }\end{array}$ & $\begin{array}{l}\text { megaspores } \\
\& \text { microspores }\end{array}$ & $\begin{array}{l}\text { megaspores } \\
\& \text { microspores }\end{array}$ \\
\hline $\begin{array}{l}\text { Megaspore } \\
\text { ornamentation }\end{array}$ & $\begin{array}{l}\text { nearly smooth, } \\
\text { tuberculate } \\
\text { or reticulate }\end{array}$ & $\begin{array}{l}\text { smooth or } \\
\text { sparsely } \\
\text { tuberculate }\end{array}$ & $\begin{array}{l}\text { finely } \\
\text { tuberculate }\end{array}$ & $\begin{array}{l}\text { finely } \\
\text { tuberculate }\end{array}$ & $\begin{array}{l}\text { smooth or } \\
\text { sparsely } \\
\text { tuberculate }\end{array}$ \\
\hline Corm lobing & $2-3$ & 2 (rarely 3$)$ & 3 & $2-3$ & 3 \\
\hline Plant habit & $\begin{array}{l}\text { spreading or } \\
\text { upright }\end{array}$ & upright & $\begin{array}{l}\text { swept sideways } \\
\text { or upright }\end{array}$ & spreading & upright \\
\hline Max. leaf length & $400 \mathrm{~mm}$ & $100 \mathrm{~mm}$ & $700 \mathrm{~mm}$ & $120 \mathrm{~mm}$ & $200 \mathrm{~mm}$ \\
\hline Mean leaf length & $100 \mathrm{~mm}$ & $75 \mathrm{~mm}$ & $300 \mathrm{~mm}$ & $75 \mathrm{~mm}$ & $100 \mathrm{~mm}$ \\
\hline $\begin{array}{l}\text { Max. mid-leaf } \\
\text { thickness }\end{array}$ & $2.5 \mathrm{~mm}$ & $3 \mathrm{~mm}$ & $2 \mathrm{~mm}$ & $1.5 \mathrm{~mm}$ & $5 \mathrm{~mm}$ \\
\hline Habitat & rivers \& lakes & rivers ( $\&$ lakes?) & rivers & $\begin{array}{l}\text { drying margins } \\
\text { of rivers, lakes } \& \\
\text { swamps }\end{array}$ & $\begin{array}{l}\text { lakes, tarns \& } \\
\text { rivers }\end{array}$ \\
\hline Altitudinal range & $20-1140 \mathrm{~m}$ & $860-1180 \mathrm{~m}$ & $20-220 \mathrm{~m}$ & $20-1020 \mathrm{~m}$ & $540-1360 \mathrm{~m}$ \\
\hline Population habit & single plants & $\begin{array}{l}\text { single plants } \\
\text { or swards }\end{array}$ & single plants & single plants & $\begin{array}{l}\text { single plants } \\
\text { or swards }\end{array}$ \\
\hline Wacer flow & $\begin{array}{l}\text { still to mod- } \\
\text { erately running }\end{array}$ & $\begin{array}{l}\text { (still?) to mod- } \\
\text { erately running }\end{array}$ & $\begin{array}{l}\text { moderately to } \\
\text { fast running }\end{array}$ & still & $\begin{array}{l}\text { still to mod- } \\
\text { erately running }\end{array}$ \\
\hline $\begin{array}{l}\text { Comparative } \\
\text { summer water } \\
\text { coverage }\end{array}$ & $\begin{array}{l}\text { exposed or } \\
\text { covered }\end{array}$ & mostly covered & covered & mostly exposed & mostly covered \\
\hline
\end{tabular}


represent the first in situ gatherings of the species in more than 150 years.

\section{Habitat and Ecology}

I. elatior grows usually in moderate to fast-flowing water, typically in a mixture of rock, gravel and silt, or in almost pure coarse sand. An exception was a site on the South Esk River, where the largest specimens seen $(0.7 \mathrm{~m}$ tall) were growing in thick mud. The species requires a year-round permanent covering of water. For example, even in mid-March when water levels are extremely low, a few small plants were observed in $0.1 \mathrm{~m}$ of water, the majority at a depth of $0.3 \mathrm{~m}$, and some as deep as $0.7 \mathrm{~m}$. Whilst the leaves of other species (even those of $I$. muelleriand $I$. drummondii) remain upright above the water surface when emergent, those of 1 . elatior lie flat against the surface.

In the South Esk, St Pauls and Break O'Day Rivers, I. elatior grows mostly with I. muelleri, with the latter usually in stiller water, and the former in deeper and faster flowing water. Perhaps because of its ultimately large size, I. elatior also appears to be more capable of resisting competition from other larger aquatic plants, such as Triglochin procera.

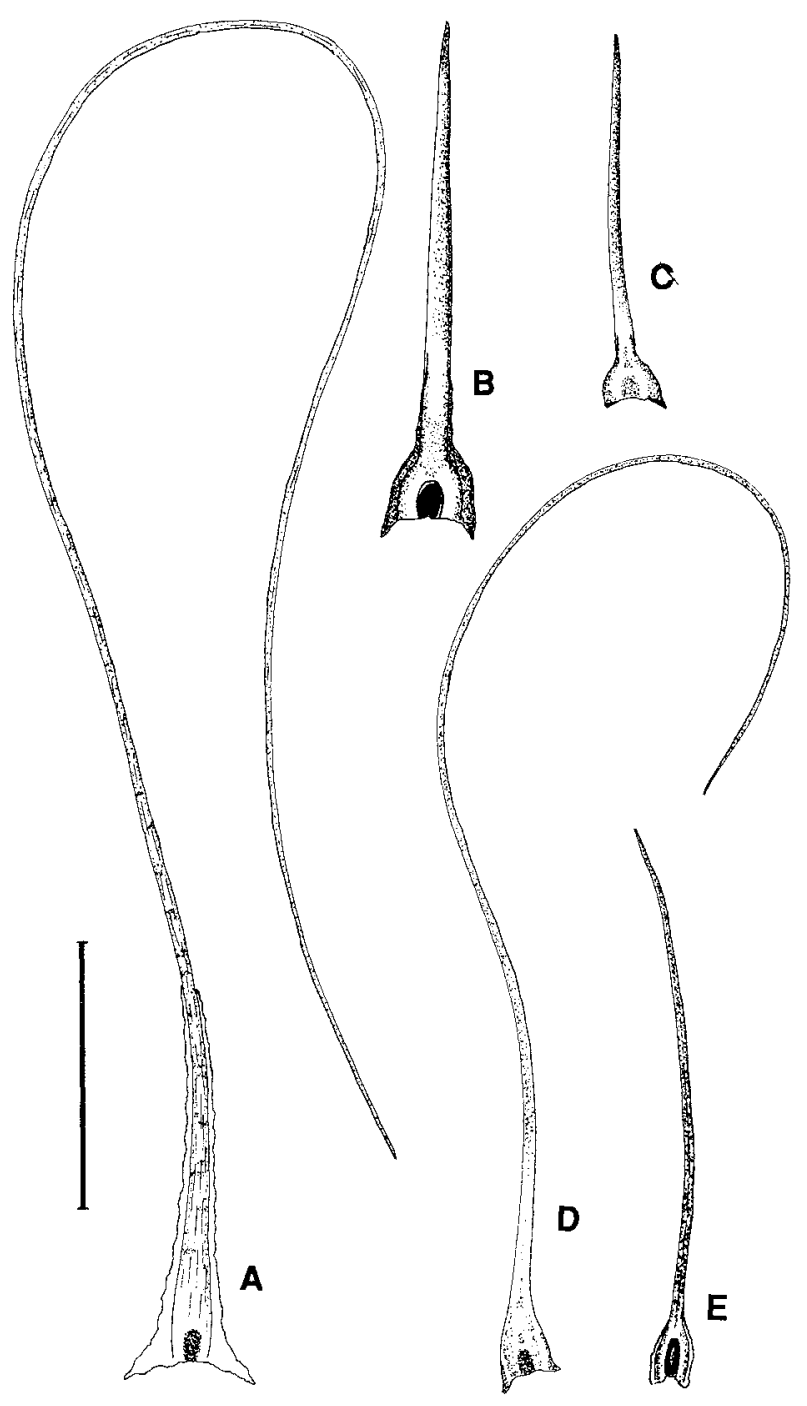

FIG. 1 - Sporophylls of Tasmanian Isoetes species: (A) I. elatior; (B) I. gunnii; (C) I. humilior; (D) I. muelleri; $(E)$ I. drummondii. Scale $=50 \mathrm{~mm}$.
Little remains of the natural vegetation at $I$. elatior localities in the South Esk River. Several serve as watering holes for stock which feed on the surrounding flats, and the river banks support scattered willows (Salix alba) and abundant gorse (Ulex europaeus). The Isoetes elatior plants at these sites are rather remarkable in their large size, with most having leaves $0.40 \mathrm{~m}$ or more in length. The larger plants also have thick bulbous bases with diameters of $40-50 \mathrm{~mm}$, caused by the profusion of leaves, up to 60 or 70 per plant.

Localities in the St Pauls and Apsley Rivers are fringed by Callitris oblonga and species of Leptospermum. Here the leaves of 1 . elatior rarely attain $0.4 \mathrm{~m}$ in length, with an average of $0.2-0.3 \mathrm{~m}$, possibly because of the shailower water flow. It is possible but unlikely that larger specimens grow in the numerous, deep, still sections of the Apsley River; the water there is always murky but even at low water levels, plants have not been seen. Overall, the Apsley River seems somewhat atypical for $I$. elatior. The river has very little water flow during the summer months, I. muelleri does not appear to occur there, and I. elatior has been found only in a $4 \mathrm{~km}$ section a few metres above sea level and $5 \mathrm{~km}$ from the sea. It has not been located in the remainder of the relatively flat and open section of the river between there and Apsley Gorge, and is unlikely to occur in the shallow waters of its catchment area.

Selected specimens examined

TASMANIA: Apsley River, M. Garrett 17.v.1990 (HO 126026). Adrift in Lake River at Longford, D.I. Morris 8.xi.1978. (HO 28160). South Esk River, 200m, M. Garrett 10.iv.1990 (HO 125862).

\section{Isoetes gunnii A. Braun}

Monatsber. K. Akad. Wiss. Berlin 535 (1868)

Diagnostic Characters (figs 1B, 2C)

Plants single or in colonies, or occurring as dense swards of dwarfed individuals. Corm 3-lobed. Leaves erect, dark green except for the white to brown-tinged basal section, very thick and rigid, to $0.2 \mathrm{~m}$ long and $5 \mathrm{~mm}$ thick in middle section, \pm flattened on the adaxial side for half their length. Sporangia large, naked and prominent, both megasporangia and microsporangia present. Megaspores smooth or sparsely tuberculate.

Notes

I. gunniican be distinguished from other Tasmanian species by its large, robust habit and by its naked sporangia.

\section{Distribution}

I. gunnii is endemic to Tasmania. It is widespread in alpine and sub-alpine areas of Tasmania, on quartzite, dolerite and sedimentary soils, ranging from Reservoir Lakes in the far south to Paddys Lake in the north, and Lakes Youl and Baker on Ben Lomond in the northeast (fig. 5). It is likely to be present in the majority of natural highland lakes and tarns.

Habitat and Ecology

I. gunnii is common in highland lakes and tarns, where it is often the sole conspicuous aquatic plant. In some shallow lakes, it can be so abundant that accumulated floating debris seems to be composed solely of its leaves, sometimes providing the only indication of the presence of the species. Whole plants or clumps of plants may also be washed ashore, probably dislodged by warer birds or wave action. The 
species does not appear to extend beyond depths of $1-1.5 \mathrm{~m}$, and in deep lakes (e.g. Lake Perry, Hartz Mountains National Park), it only fringes the shoreline. Whilst tightly packed clumps of perhaps hundreds of plants occur in rocky shallows, the largest, most robust plants, often occurring individually, are found in thick mud and silt, often with only the top third visible above the substrate. Germinating sporelings within decaying sporangia in leaf axils have been observed in small loose clumps of plants and presumably in this manner, more dense clusters are developed.

Plants in exceptionally small, shallow tarns may be completely yellow or blackened, possibly due to increased or fluctuating water temperatures. Stunted plants in very shallow water can be exposed during summer months, but seldom by more than a few centimetres above water level (never as much as I. muelleri or I. drummondit) and survive by being buried deep in mud, amongst rocks or within the protection of large clumps. Exposed plants, freshly grazed back to the rootstock, have also been observed, suggesting the species may be palatable to native animals.

I. gunnii is less common in running water, although quite large specimens occur in calmer areas of silt build-up, while smaller or clump-forming plants are found in quicker flowing water and rockier sections. Colonies of both large and small plants have been observed in the slow moving sections of the Little Pine River and the uppermost parts of the Derwent River, as well as in the Nive River and Pine Tree Rivulet.

In the Central Plateau area, $I$ gunnii often grows with $I$. muelleri, with the former dominant and favouring deeper water. In the Ouse and Little Pine Rivers, populations of $I$. gunnii and $I$. humilior grow side by side, often intermingled in the same clumps, and here the extent to which these two species are vegetatively similar is most apparent. At Fergies Paddock on the southwestern shore of Lake St Clair, and in the Little Pine River, Pilularia novae-hollandiae also occurs with I. gunnii, its rhizome often creeping amongst the leaves of Isoetes.

I. gunnii does not appear to be as successful as either $I$. muelleri or I. drummondii in re-establishing itself in artificial waters. However, it is quite common at the northern end of St Clair Lagoon, and has also established in what appears to be a constructed canal connecting the lagoon to Lake $S t$ Clair at the pumping station. HEC work at this site was completed in 1935 (J. Linton, pers. comm.), and it would seem that $I$ gunnii requires at least this length of time for re-establishment.

\section{Selected specimens examined}

TASMANIA: Milligans Peak, S.J. Jarman 28.i.1984 (HO 100595). Ladies Tarn, Hartz Mountains, $980 \mathrm{~m}$, A. E. Orchard 11.ii.1980 (HO 33034). Lake Curly, 700 m, G. Kantvilas 8.ii.1985 (HO 89427), LakeSydney, G. Kantvilas 17.xii.1982 (HO 74908).

\section{Isoetes humilior F. Muell. ex A. Braun Linnaea 25: 722 (1852)}

Diagnostic Characters (figs 1C, 2B)

Plants single, in colonies, or more commonly in dense swards of dwarfed plants. Rootstock often not distinctly corm-like, but with 2 (rarely 3 ) very elongated lobes. Leaves erect, thick and rigid, dark green except for the white to brown-tinged basal section, to $0.1 \mathrm{~m}$ long and $3 \mathrm{~mm}$ thick in middle

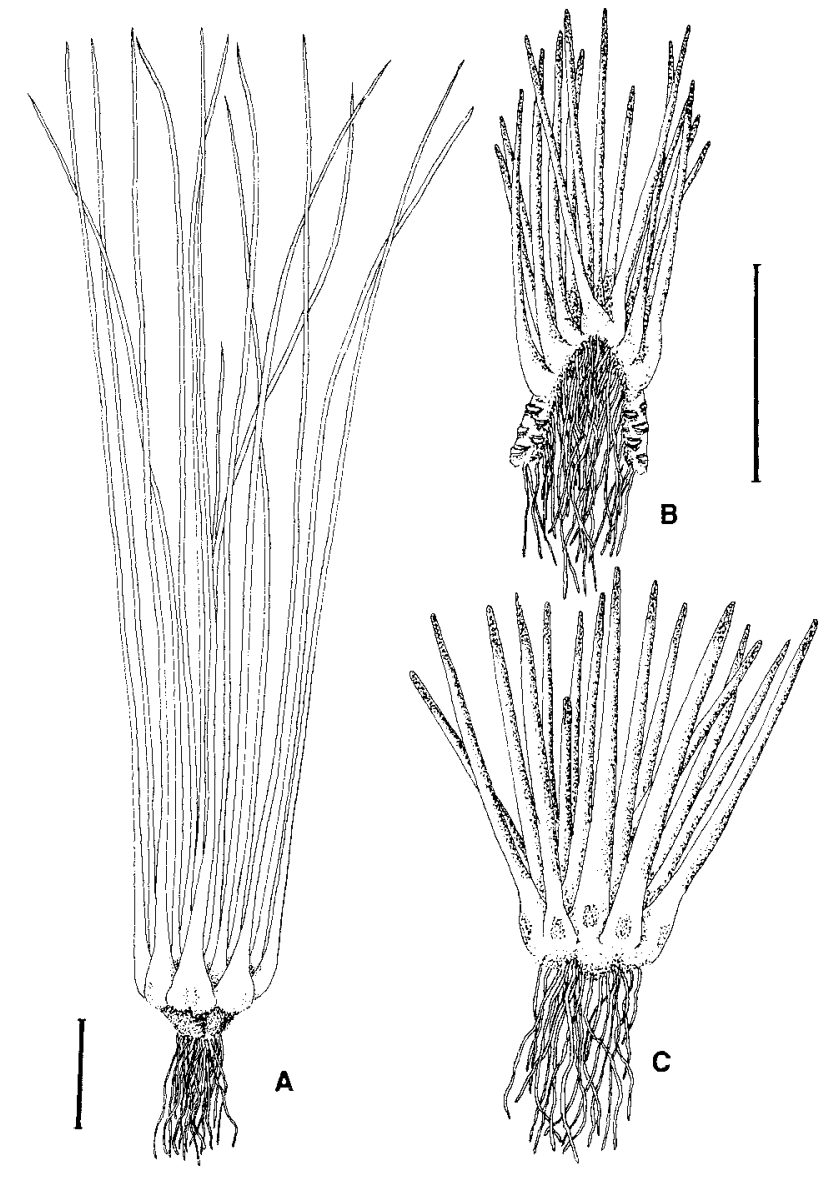

FIG. 2 - Tasmanian endemic Isoetes species: (A) I. elatior; (B) I. humilior; (C) I. gunnii. Scale $=5 \mathrm{~cm}$.

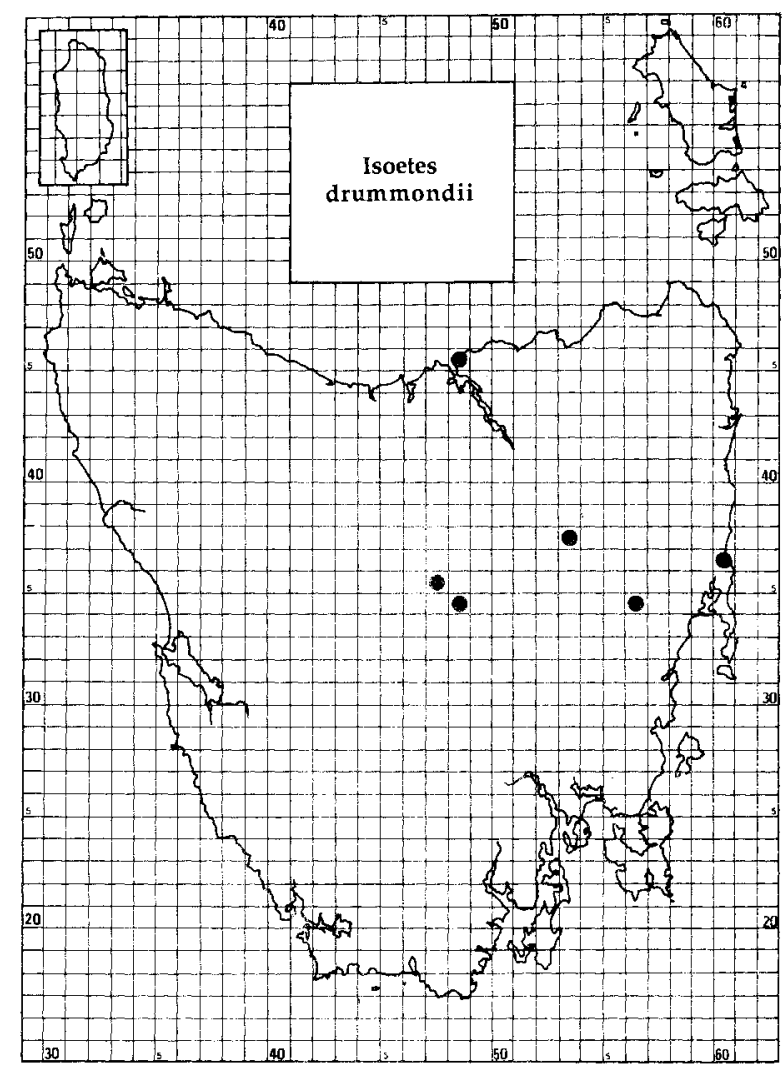

FIG. 3.-Distribution of Isoetes drummondii in Tasmania. 


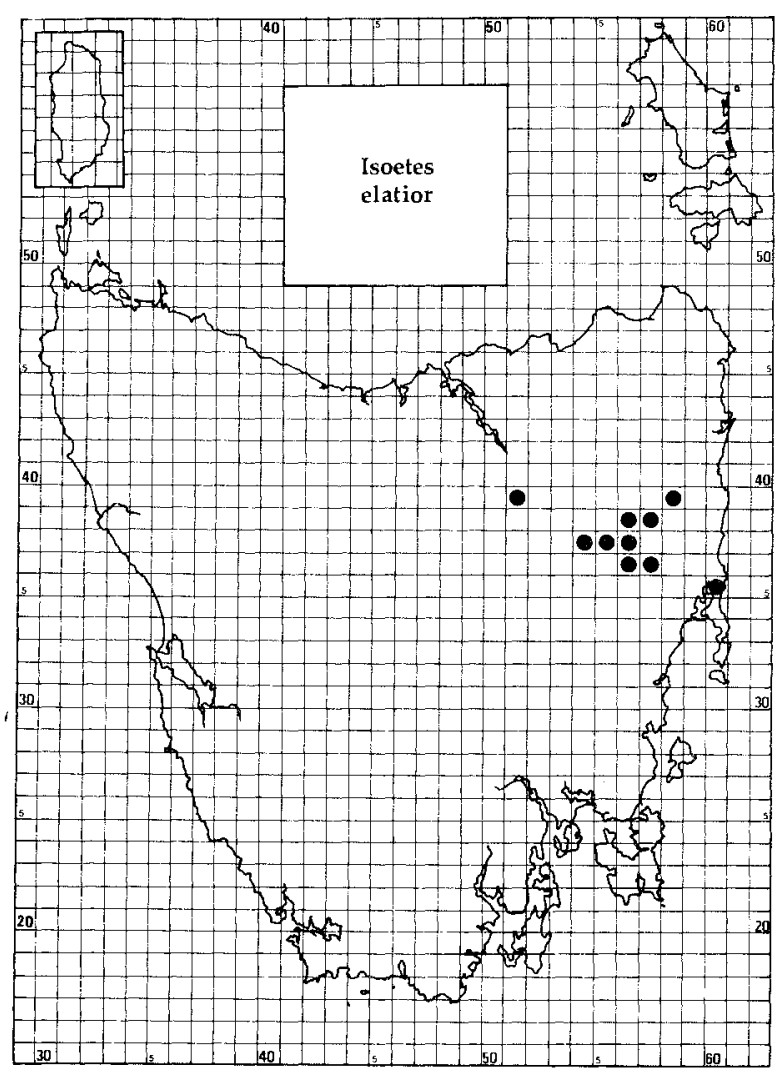

FIG. 4 - Distribution of Isoetes elatior in Tasmania.

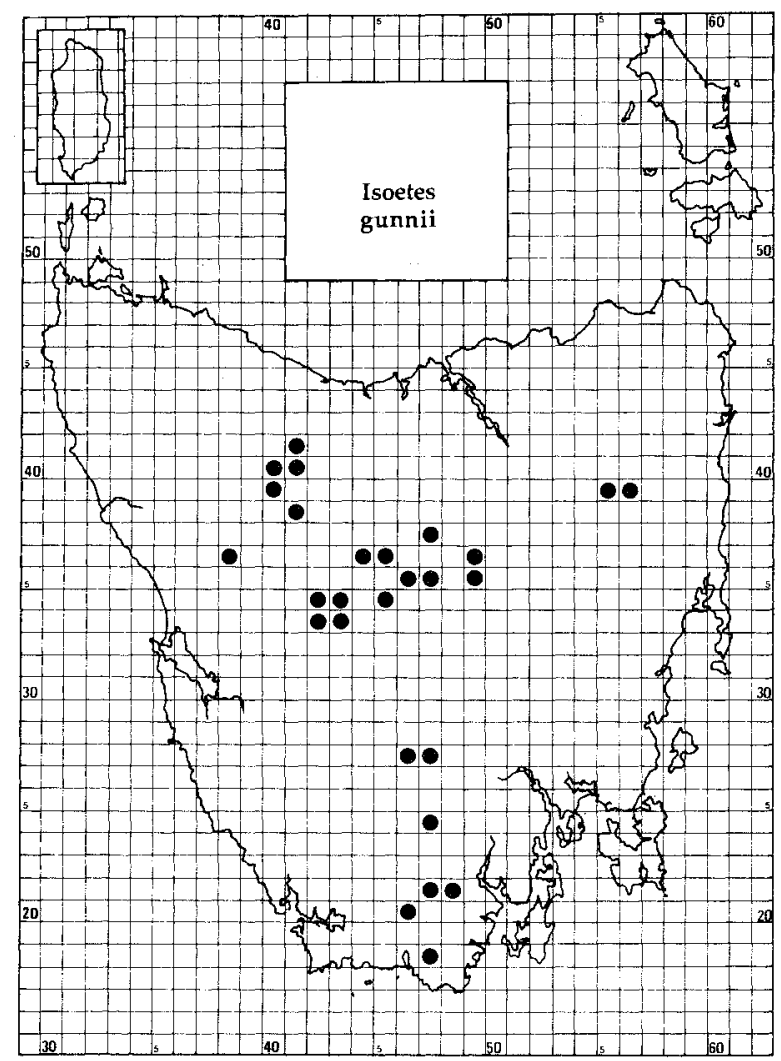

FIG. 5 - Distribution of Isoetes gunnit in Tasmania. section, flattened on the adaxial side towards the base only. Sporangia completely (rarely partially) covered by a velum, both megasporangia and microsporangia present. Megaspores smooth or sparsely tuberculate.

\section{Notes}

In the field, I. humilior can be easily confused with I. gunnii, as both share the same habitat, growth habit, colour and leaf shape. On average, the leaves of I. humilior are shorter and thinner but nevertheless fall within the size range of those of I. gunnii, particularly when both species occur in communal clumps. However, I. humilior is distinguished by the presence of a velum covering the sporangia. Furthermore, its corm is usually bilobed, albeit rather indistinctly, whereas that of $I$. gunnii is distinctly tri-lobed. Sporangia covered by a velum are also found in the widespread and variable species, $I$. muelleri. Previous scant knowledge of I. humilior, and the misapplication of this name to forms of I. muelleri in the past, e.g. by Wakefield (1955) and Jones \& Clemesha (1976), has led to some suggestion that the former is a hardened highland variant of the latter. However, the present survey indicated that I. muelleri always retains its characteristic soft foliage, even when growing with $l$. humilior, and is thus easily distinguishable in gross morphology. I. humilior can further be separated from I. muelleriby its elongated bi-lobed corm: although often bi-lobed, the corm of $I$. muelleri is distinctly rounded.

\section{Distribution}

I. humilior is endemic to Tasmania. During the present survey, it has been recorded only from the Central Plateau where it is occasional in the Ouse, Little Pine and Shannon Rivers. Dislodged plants have also been collected on the shores of Gunns Lake, Little Lake, Lake Fergus and St Clair Lagoon (fig. 6).

Whilst this distribution pattern, as well as the tough texture of its leaves, suggests that $I$. humilior is an alpinesubalpine species, it is interesting to note that Braun's type specimen (collected by Charles Stuart) is from the South Esk River. No collections of this species were made in this river system during the present survey and, despite supporting other species of Isoetes in its lower reaches, the river appears to lack suitable habitats for $I$. humilion. It is possible that Braun's type may have been a dislodged plant which entered the South Esk River via the streams which drain the northern parts of the Central Plateau.

\section{Habitat and Ecology}

The ecology of I. humilior remains poorly understood. It appears to have a preference for running water, especially shallow, slow-moving rivers, where it grows under similar conditions to those of $I$. gunnii. The largest plants are found in deeper, slower flowing water, while dwarfed communal clumps are more frequent amongst the cleaner rocky beds in fast currents. In February, when water levels are near or at their lowest, the majority of plants remain in 0.15 to $0.2 \mathrm{~m}$ of water, although some may have their tops emergent. However, completely exposed individuals are uncommon. Overall, I. humilioroccurs as clumps more often than I. gunnii, and germinating sporelings within the clumps are common.

Selected specimens examined

TASMANIA: St Clair Lagoon, 737 m, M. Garrett20.ii.1991 (HO 126563). Ouse River near Lake Augusta, $1160 \mathrm{~m}, M$. Garrett 31.i.1990 (HO 125863). 


\section{Isoetes muelleri A. Braun}

Monatsber. K. Akad. Wiss. Berlin 541 (1868)

Diagnostic Characters (fig. 1D)

Plants single or in colonies. Corm 2-or 3-lobed. Leaves erect or spreading, light to dark green except for a pale or white buried basal section, flexible and slender, to $0.2(-0.4 \mathrm{~m})$ long and $2.5 \mathrm{~mm}$ thick in middle section, flattened on the adaxial side for half the length. Sporangia completely (rarely partially) covered by a velum; only megasporangia present. Megaspores variable in size, shape and ornamentation, even within a single sporangium; ornamentation almost smooth, tuberculate or reticulate.

\section{Notes}

I. muelleri can be distinguished from the other Tasmanian species by the presence of a velum covering the sporangia, and by its soft leaves. No microspores have been observed in this species which appears to be strongly apomictic.

Some plants have extraordinarily enlarged corms, formed by the swollen sporangia bulging the abaxial side of the leaf base. This feature, also known in populations of $I$. drummondii, appears to be restricted to plants which must survive a prolonged period of relative dryness out of water. Individuals that are normally covered with algae when submerged tend to become smothered and flattened by the weight of the drying algae when the water level drops and the plant is exposed. Normally 'clean' plants have upright although slightly contorted leaves when exposed for some time. The plant's top growth dies back if the substrate becomes excessively dry.

\section{Distribution}

I. muelleri appears to be much more widespread than previously thought. It is most abundant in, but not confined to, the relatively flat land of the Central Plateau, Derwent Valley, Fingal Valley and Midlands, ranging from the Derwent River at New Norfolk in the southeast, to Lake St Clair in the west, Lake Trevallyn in the north, and to the Break O'Day and St Pauls Rivers in the east (fig. 7). It has a wide altitudinal range, from $20 \mathrm{~m}$ on the lower Derwent, to at least $1140 \mathrm{~m}$ at Second Lagoon on the Central Plateau. I. muelleri also occurs in all Australian states and territories (Marsden 1976).

\section{Habitat and Ecology}

I. muelleri occurs in the mud of shallow sections of rivers and lakes. It is usually submerged in at least $0.3-0.5 \mathrm{~m}$ of water for most of the year, with the largest plants occurring in deeper permanent water to a depth of $1.5 \mathrm{~m}$, as for example, at the northern end of St Clair Lagoon. Such individuals can be difficult to locate because the whole plant, including new emerging leaves, is covered in a thick layer of algae and silt. In this condition, the species is easily overlooked. During the two to three months of summer, some plants may be exposed to $0.5 \mathrm{~m}$ above the water level. Such plants become sunbleached yellow-green but remain quite healthy, growing in moist although not saturated mud.

The species is also known as a more-or-less free floating plant in fine silty mud, e.g. some metres from the shore in Penstock Lagoon, while in lakes such as Gunns Lake, Lake Sorell and Lake St Clair, it occurs in mud amongst rocks. In faster flowing sections of rivers, e.g. in the upper and lower Derwent River, Ouse River, Pine Tree Rivulet and Nive River, stunted plants may occur on the lee side of large rocks or in the sediment-filled cracks in rock platforms.

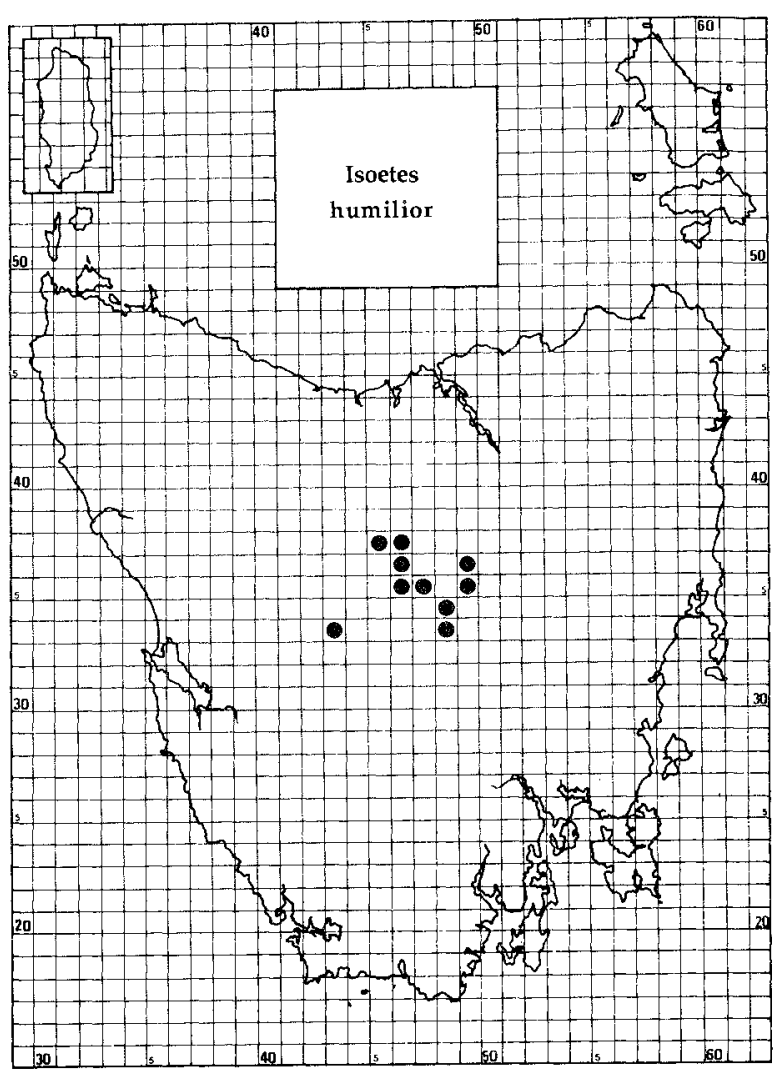

FIG. 6 - Distribution of Isoetes humilior in Tasmania.

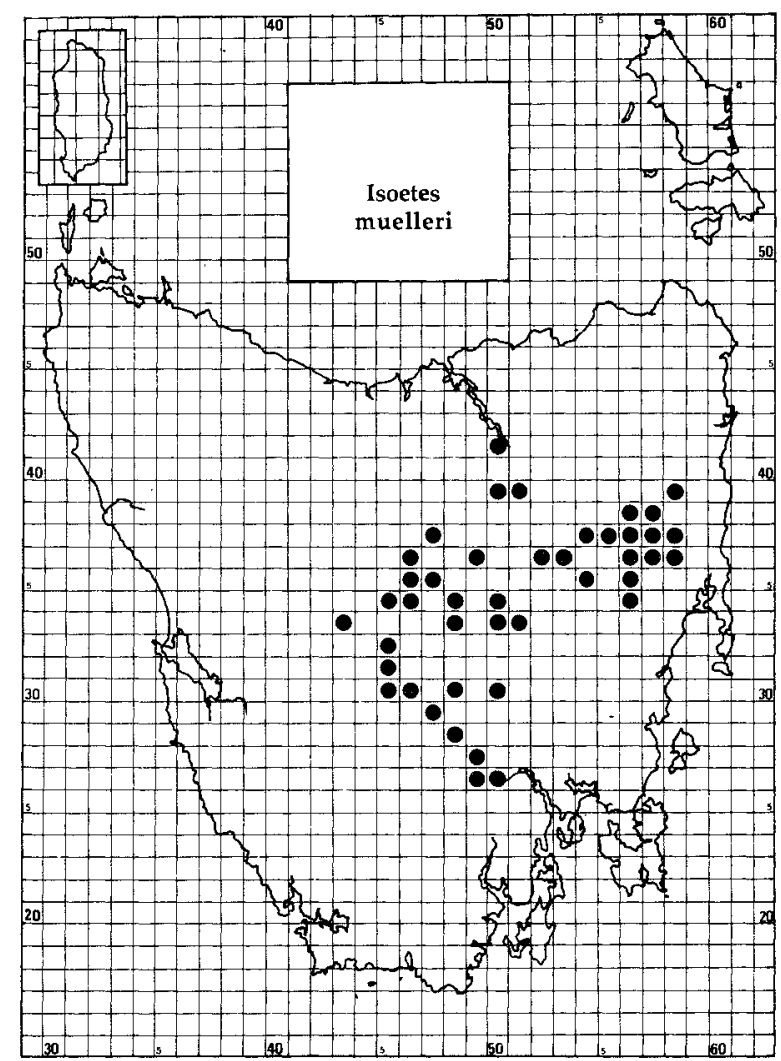

FIG. 7 - Distribution of Isoetes muelleri in Tasmania.

I. muelleri is most abundant at the wide, shallow margins of some highland lakes, particularly constructed impoundments such as Bronte Lagoon and Wayatinah Lagoon. These 
waters all provide a large expanse of shallow water with a firm and slightly gravelly mud substrate, consolidated by other small aquatic plant species. The presence of larger plants, such as reeds, appears to be an important factor in the establishment and survival of 1 . muelleri, and may impede spore dispersal or produce conditions which are too shaded. Populations of I. muelleri are especially prolific on the eastern margins of these lakes, perhaps due to the dispersal by prevailing westerly winds of spores and whole plants dislodged by wave action, browsing waterfowl and fish. The origins of populations of $I$. muelleri in artificial waters requires further study. The species may have already been present in pre-dammed smaller lakes and marshes, or have spread from natural waters by the action of currents or waterfowl.

I. muelleri can be found growing with each of the other Tasmanian species of Isoetes. In the South Esk, Break O'Day and St Pauls Rivers, it occurs in still backwaters, close to I. elatior, which occurs in rockier and faster flowing water. In Lake Leake, Shannon Lagoon and Wihareja Lagoon, the species grows with I. drummondii, although in deeper water than that species. In Little Pine River, Pine Tree Rivulet, Gunns Lake, Nive River, Lake St Clair and the upper Derwent River, I. muelleri can co-occur with $I$. gunnii although there the former is usually found in shallower water. In the Shannon and Little Pine Rivers, it grows with I. humilior. The rare aquatic fern, Pilularia novae-hollandiae, may also be associated with $I$. muelleri .

\section{Selected specimens examined}

TASMANIA: St Pauls River at Avoca, $200 \mathrm{~m}, M$. Garrett 10.iv. 1990 (HO 125860). South Esk River, $8 \mathrm{~km}$ northeast of Avoca, $200 \mathrm{~m}$, M. Garrett 10.iv.1990 (HO 125859). Elizabeth River, $200 \mathrm{~m}$ downstream of Lake Leake Dam, 560m, M. Garrett 27.iv.1990 (HO 125861). Macquarie River, $10 \mathrm{~km}$ west of Campbell Town, $160 \mathrm{~m}, M$. Garrett 10.iv. 1990 (HO 125857). Lake Sorell, Interlaken, $800 \mathrm{~m}$, D.I. Morris 25.iv.1975 (HO 126585).

\section{CONSERVATION STATUS OF THE GENUS IN TASMANIA}

Although none of the known populations of Isoetes in Tasmania appear to be under any immediate threat, not all the species are represented within reserves.

I. drummondii is at present unknown from any protected areas, although it occurs on the Central Plateau and further investigations may reveal populations within the World Heritage Area. Populations worthy of consideration for conservation exist at Wihareja Lagoon (where it occurs together with I. muelleri and Pilularia novae-hollandiae), and at Ladies Mile Marsh on the Eastern Tiers.

I. elatior, a Tasmanian endemic and one of the largest Australian species in the genus, is most in need of protection. It is completely unreserved, and all known populations are on private land. A private reserve (for Callitris oblonga) on the lower Apsley River is just downstream from the lowest known population of $I$. elatior, and it is highly unlikely that this species would occur far enough upstream to be within the Douglas-Apsley National Park. Unique problems are associated with the location of reserves for aquatic species. Riverbank reservation does not necessarily guarantee the protection of populations at that site, as influences from upstream activities are just as consequential for their survival. A combination of riverbank, upstream, and catchment reservation would seem desirable.
The endemic 1. gunnii is common and widespread, and well protected in a number of reserves, including Mt Field National Park and the World Heritage Area.

While the exact distribution of the endemic I. humilior is unclear, populations on the Ouse River are also well inside the World Heritage Area.

I. muelleri is common and widespread, and well-reserved within the World Heritage Area. It has been overlooked in the past, and is likely to occur in other protected areas as well. This species appears to have been favoured by the formation of hydro-electric impoundments.

In general, most riverine habitats suitable for Isoetes (especially I. muelleriand I. elatior) also tend to be ideal for agriculture, and the native riverbank vegetation has usually been cleared to pasture, replaced by invasive introduced plants such as willow, gorse and blackberry, or is frequented by grazing stock. It is possible that the roots of willow, which form a thick mat submerged at about the depth required for Isoetes, may be detrimental. However, it is also possible that build-up of silt due to agricultural practices, may have enhanced riverbed populations. The overall effect of hydro-electric development on the species (excluding I. muelleri) is unclear.

\section{ACKNOWLEDGEMENTS}

We thank Drs M.J. Brown, R.J. Chinnock and S.J. Jarman for comments on the manuscript, and Mr M. Neyland for permission to incorporate some of his locality data. Financial support to the first author from the Tasmanian Forest Research Council is gratefully acknowledged.

\section{REFERENCES}

Brown, M.J., KirkPatrick, J.B. \& Moscal, A., 1983: AN ATLAS OF TASMANIA'S ENDEMIC FLORA. Tasmanian Conservation Trust, Hobart.

BROWNSEY, P.J. \& SMITH-DODSWORTH, J.C., 1989: NEW ZEALAND FERNS AND ALLIED PLANTS. David Bateman, Auckland.

DUNCAN, B.D. \& ISAAC, G., 1986. FERNS AND ALLIED PLANTS OF VICTORLA, TASMANLA AND SOUTH AUSTRALLA. Melbourne University Press, Carlton, Victoria.

Hat.L. J.B., 1971. Observations on Isoetes in Ghana. Bot. J. Linn. Soc. 64: 117-139.

HICKeY, R.J., 1990. Studies of neotropical Isoetes L. 1. Euphyllum a new subgenus. Ann. Miss. Bot. Gard. 77: 239-245.

HiCKhy, R.J., TAYLOR, W.C. \& LueBKE, N.T., 1989. The species concept in Pteridophyta with special reference to Isoetes. Am. Fern J. 79 (2): 78-89.

JermY, A.C., 1990. Isoetaceae. In Kramer, K.U. \& Green, P.S. (Eds): THE FAMILIES AND GENERA OF VASCULAR ILANTS, VOL. I: PTERIDOPHYTES AND GYMNOSPERMS. Springer-Verlag, Berlin: 25-31.

JoHnSON, E.R.L., 1984. Taxonomic revision of Isoetes L. in Western Australia. J. R. Soc. West Aust. 67: 28-43.

JONES, D.L. \& Cl.EMESHA, S.C., 1976. AUSTRALIAN FERNS AND FERN ALLIES. Reed, Sydney.

LEACH, G.J. \& OSBORNe, P.L., 1985. FRESHWATER PLANTS OF PAPUA NEW GUINEA. University of Papua New Guinea Press, Port Moresby.

Marsden, C.R. 1976. Morphological variation and taxonomy of Isoetes muelleri. A. Br. J. Adelaide Bot. Gard. 1: 37-54.

Mickel., J.T., 1979. HOW TO KNOW THE FERNS AND FERN ALLIES, Brown, lowa

WAKFFIELD, N.A., 1955. FERNS OF VICTORIA AND TASMANLA. Field Naturalist Club of Victoria.

(accepted 1 May 1992) 